\title{
Iris Melanoma pT4a TNM Finding v8
}

National Cancer Institute

\section{Source}

National Cancer Institute. Iris Melanoma pT 4a TNM Finding v8. NCI Thesaurus. Code C140628.

Iris melanoma with extrascleral extension $5 \mathrm{~mm}$ or less in largest diameter. (from AJCC 8th Ed.) 